\title{
Samsun'da Catering Hizmet Sektörünün İyi Hijyen Uygulamaları Profili
}

\author{
Sibel Özçakmak ${ }^{1}$, Osman Gül ${ }^{2}$ \\ ${ }^{I}$ Glda, Tarlm ve Hayvancllık İl Müdürlüğü, Gıda ve Yem Șubesi, 55060 Samsun, Türkiye \\ ${ }^{2}$ Ondokuz Mayıs Üniversitesi, Yeşilyurt Demir Çelik Meslek Yüksekokulu, Gıda İsleme Bölümü, 55300, Samsun, Türkiye
}

M A K A L E B İ L G İ S İ

Geliş 31 Mayıs 2016

Kabul 16 Kasım 2016

Çevrimiçi bask1, ISSN: 2148-127X

\section{Anahtar Kelimeler:}

Catering

Reel üretim kapasitesi

İyi hijyen uygulamaları

Gıda güvenliği

Yasal mevzuat

*Sorumlu Yazar:

E-mail: damla-damla49@hotmail.com
Ö Z E T

Tabldot yemek üretim ve dağıtım faaliyeti gösteren işletmelerin, yemeklerin tüketime sunulmadan önce Gıda Hijyeni Yönetmeliği ve diğer ilgili yasal gerekliliklere uygun olup olmadığı ile ilgili veriler oldukça yetersizdir. Bu nedenle, Samsun ili merkez ve ilçelerinde 5996 sayılı Veteriner Hizmetleri, Bitki Sağlığı ve Gıda ve Yem Kanunu'na göre kayıtlı yemek üretim ve dağıtımı yapan işletmelerin mevcut koşulları ve çalışan personelin iyi hijyen uygulamaları profilini ortaya koymak amacı ile bir anket çalışması yürütülmüş̧ür. Araştırma Catering işletmelerinin faaliyet gösterdikleri 9 ilçede bulunan toplam 32 işletmede, 258 kişi (mutfak bölümünde çalışan personel ve sorumlu yöneticiler) ile yüz yüze görüşülerek ve aynı zamanda işletme koşulları gözlemlenerek uygulanmıştır. Anket soruları, çalışanların cinsiyeti, yaşı, eğitim düzeyi, mesleki tecrübe yıl1, reel üretim kapasiteleri, makine gücü, üretimde çalışan personel sayısı, iyi hijyen uygulamalarına ait bulguları kapsamaktadır. Üretim alanı tasarım ve yerleşiminin bazı işletmelerin iyi hijyen uygulamaları açısından yeterli olmadığı, pozitif hava basınçlı havalandırmanın sadece dört işletmede bulunduğu görülmüştür. Mutfakta kullanılan aletekipmanlarda korozyon riskine karşı daha fazla önlem alınması gerektiği, gıdaların nakliyesinde sıcaklığın korunması açısından genellikle uygun kapların kullanıldığı belirlenmiştir. İşletmenin temizlik ve dezenfeksiyonu, kişisel hijyen kurallarının uygulanması ve dondurulmuş gıdaların çözündürülme işlemlerinde önemli düzeyde yetersizlik görülmüştür. İzlenebilirlik için kayıt formlarının yetersiz olduğu tespit edilmiştir. Faaliyet alanına göre hazır yemek üretimi yapan işletmeler, yüksek risk grubunda bulunduğundan nitelikli bir ekibin kurulması ve bu ekip tarafindan hijyen uygulamalarının iyileştirilmesi gerekmektedir. Catering sektöründe gıda güvenliği yönetim sistemi kurulması ile tehlike ve risk faktörlerinin kontrol altına alınması sağlanmalıdır.

Turkish Journal Of Agriculture - Food Science And Technology, 4(11): 1031-1038, 2016

The Profile of Good Hygiene Practice of Catering Service Sector in Samsun

\section{A R T I C LE IN F O}

Article history:

Received 31 May 2016

Accepted 16 November 2016

Available online, ISSN: $2148-127 \mathrm{X}$

Keywords:

Catering

Real production capacity

Good hygiene practices

Food safety

Legislation

*Corresponding Author:

E-mail: damla-damla49@hotmail.com

\section{A B S T R A C T}

Before serving the meals, the managements that operate in the production and distribution of table d'hôte meals, the data related to whether it's appropriate for the food hygiene regulation and the other legal requirements are so insufficient. So, an interview study was performed for the present conditions of the manufactures producing and serving meals and the good hygiene practices profile of their working personal in the plants with regard to Law No.5966 on Veterinary Services, Plant health, Food and Feed in the Samsun city. The survey was applied in catering enterprises and face to face interviews with a total of 258 people (employees and managers responsible for the kitchen area) and at the same time observing the operating conditions of 32 companies in 9 different counties. The questions of survey included gender, age, education level, professional experience of workers, real production capacities, the power of engine, number of employees in production, and findings related to good hygiene practice. It was observed that the design and layout of the production area in terms of good hygiene practices were not sufficient in some manufactures and only four manufactures had positive air pressure ventilation. It was stated that tools and equipment were required to take more precautions against the risk of corrosion. It was established that cleaning and disinfection process, personal hygiene rules and dissolving operations for frozen food were inadequate. It was determined that record forms were not sufficient to provide the traceability. Hazard and risk factors will be controlled by establishment of practical food safety management system in catering sector. 


\section{Giriş}

Endüstrileşme ile beraber ev dışında başkaları tarafindan belirlenen, organize edilen ve hazırlanan yiyecek içecek hizmetleri toplu beslenme hizmeti olarak adlandırılmakta olup (halk arasında tabldot olarak adlandırılmakta) son yıllarda önemli düzeyde artış göstermektedir (Kılıç, 2002; Bilgin ve Erkan, 2008). 5996 sayılı Veteriner Hizmetleri, Bitki Sağlığı ve Gıda ve Yem Kanunu'nda belirtilen koşulları sağlayan kayıtlı 4800'ün üzerinde tabldot yemek üreten işletme mevcuttur. Hazır yemek, tabldot yemek ve meze üreten işyerleri, bağ $l_{1}$ oldukları İl Gıda, Tarım ve Hayvancılık Müdürlüklerine (GTHB) İşletme Kayılt Belgesi başvuru ve beyannamesi ile müracaat ederek, "Depo, gıda satış ve diğer perakende faaliyet gösteren işletmeler" olarak kayıt altına alınmaktadır (Anonim, 2013). GTHB denetimlerinde, öncelikle 5996 sayılı gıda kanunu kapsamında Gıda Hijyeni Yönetmeliği gereklilikleri, İyi Hijyen Uygulamaları Kılavuzu'nda belirlenen genel ve özel hijyen koşulları, Hayvansal Gıdalar İçin Özel Hijyen Yönetmeliği başta olmak üzere ilgili dikey ve yatay tüm yönetmelik ve buna bağlı tebliğlere göre işletmeler değerlendirilmektedir (Anonim, 2010).

İşletme mutfaklarında gıda hijyenine dikkat etmek ve sağlıklı gıda üretmek, israfın ve uygulama hatalarından kaynaklanabilecek maliyet ve zaman kayıpları ile güven problemlerinin de önüne geçecektir. "Bir doktor bir kişi, bir aşçı 1000 kişi üzerinde etkilidir" ifadesinden de anlaşılacağı üzere hijyen esaslarının uygulanmasının herhangi bir basamağında oluşabilecek aksaklık, toplu gıda zehirlenmeleri ve/veya ölümlere neden olabilmektedir. Türk Gıda Kodeksi (TGK) Mikrobiyolojik Kriterler Yönetmeliği'ne göre, Stafilokokal enterotoksinler, Bacillus cereus, Salmonella spp., Esherichia coli, Listeria monocytogenes, "Gıda Güvenliği Kriterleri" sınıfinda yer almakta olup, kabul edilebilir limit değerlere gıda işletmecileri tarafından uygunluk gösterilmesi gerekmektedir (Anonim, 2011a).

Mutfak disiplini ve personel tutum ve davranışlarının iyileştirilebilmesi için hijyen eğitimleri Sorumlu Yönetici tarafindan yerine getirilmelidir. Üretimin her aşaması riske açık olup, uzman bir ekip lideri tarafından işletmenin kendine özgü iş akışına göre hazırlanan kalite kontrol sistemi ile gıda güvenilirliği şartları sağlanmalıdır. Tabldot yemek üretiminde, yemekler tüketime sunulmadan önce taşıma, depolama, hazırlama, pişirme, soğutma gibi birçok aşamada insan sağlığı için tehdit oluşturabilecek fiziksel, kimyasal veya mikrobiyolojik tehlikeleri kontrol etmek, izlenebilirliğini sağlamak ve personelin hizmet kalitesini arttırmaya yönelik eğitimlerin yürütülmesinde "İstihdamı Zorunlu Personel" büyük rol oynamaktadır (Akçadağ ve Yıldıım, 2004).

Beyhan (1993), Boyacıoğlu (1996), Dündar ve ark. (2000) ve Akçadağ ve Yıldırım (2004), ülkemizde toplu beslenme sistemlerinde hijyen durumu ve sektörün genel durumunu ortaya koyan çalışmalar yürütmüşlerdir. Ancak, toplu tüketim olarak değerlendirilen çalışmaların yanında, catering işletmelerinin gıda hijyeni uygulamaları konusunda envanterlerin ortaya konması için saha çalışmalarının yetersiz olduğu görülmektedir. Toplu yemek hizmeti veren işletmelerde üretim alanlarının planlanması, dizaynı ve yapı malzemelerinin seçimi, hijyenik üretimin sağlanmasında temel basamakları oluşturmakta olup üretim alanının tasarımında, hijyenik yaklaşım prensibine göre yerleşim ve malzeme temini sağlanmalıdır. Yasal mevzuata uygunluğu açısından Gıda Hijyen Yönetmeliği, Gıda, Tarım ve Hayvancıllk Bakanlığı'nın ilgili sektörlere yönelik yayımlanmış olan "Hijyen Esasları ve İyi Uygulama Kılavuzu"nda belirtilen koşullar başta olmak üzere, genel ve özel hijyen için gerekli tüm koşullar sağlanmalıdır (Anonim, 2010; Anonim, 2011b).

Catering sektörünün alt yapısı, gıda hijyeni uygulamaları, personel eğitim durumu gibi konular ile ilgili sektör yetkilileri ile görüşmeler ve literatür araştırmaları sonucunda, hazır yemek üretim ve dağıtımını yapan işletmelere yönelik demografik dağılım, personel hijyen uygulamaları, gıda hijyeni ve işletmenin hijyenik tasarım anlayışı kapsamında yürütülen çalışmalar oldukça yetersizdir (Boyacıoğlu, 2003; Bilgin ve Erkan, 2008; Sucu ve ark., 2008; Sezgin ve ark., 2013). Bu çalışma, Samsun'da faaliyet gösteren tabldot yemek üreten ve dağıtımını yapan kayıtlı işletmelerin, genel ve gıda hijyen kriterlerine uygunluğu, üretimde görevli personelin sosyo-demografik özellikleri ve üretim kapasite değerlerini tespit etmek amacı ile yürütülmüştür. Samsun ili ve Karadeniz Bölgesinde yürütülen catering sektörüyle ilgili bu kapsamda yapılan ilk çalışmadır. Saha çalışmaları ile ilgili elde edilen bulgular, sektör yetkilileri ve çalışanlar için gıda hijyeni konusunda farkındalık yaratması ve tespit edilen eksikliklerin iyileştirilmesi açısından faydalı olacaktır.

\section{Materyal ve Metot}

Çalışma, Kasım 2014 - Ocak 2015 tarihleri arasında Samsun il ve ilçelerinde bulunan kamu ve özel tabldot yemek üretim ve dağıtımı yapan toplam 32 işletmeye (29 özel, 3 kamu) uygulanmıştır. Anket çalışmasından önce kurum izni alınmış ve işletme yetkilileri bilgilendirilmiştir. Genel Hijyen Yönetmeliği ve Hijyen Esasları ve İyi Uygulama Kılavuzu'nda yer alan gereklilikler göz önünde bulundurularak (Anonim, 2011a; Anonim, 2011c) çoktan seçmeli 22 sorudan oluşan anket çalışması yürütülmüştür. Çalışma, catering işletmelerinin faaliyet gösterdikleri adreslerde, mutfak bölümünde çalışan personel ve sorumlu yöneticilerle (258 kişi) yüz yüze görüşülerek uygulanmıştır. İşletme kayıt belgesine sahip toplam 43 işletmenin 32'si gönüllü olarak ankete katılmıştır. Vardiya saatleri anketin uygulandığı saatlere denk gelmediği için 11 işletme ankete katılamamıştır. Anket sonuçları bilgisayar ortamına taşınarak Excel tabloları oluşturulmuş, sonuçlar sorulara verilen cevap sayısı üzerinden yüzde olarak değerlendirilmiştir.

\section{Bulgular ve Tartışma}

Araştırmada elde edilen bulgular, demografik veriler (Çizelge 1-2) ve gıda hijyeni uygulamalarına ilişkin veriler olarak (Çizelge 3-8) iki ana başlıkta toplanmıştır. Katılımcıların verdikleri cevaplar, sayı (n) ve yüzde (\%) değeri olarak çizelgelerde sunulmuştur. 
Çizelge 1 Katılımcıların demografik özellikleri

\begin{tabular}{|c|c|c|}
\hline Cinsiyet & $\overline{\mathrm{n}}$ & $\%$ \\
\hline Erkek & 132 & 51,2 \\
\hline Kadın & 126 & 48,8 \\
\hline Yas aralı̆̆1 & & \\
\hline $20-30 \mathrm{y} 1 \mathrm{l}$ & 65 & 25,2 \\
\hline $31-40 \mathrm{y} 11$ & 100 & 38,8 \\
\hline $41-50$ y1l & 78 & 30,2 \\
\hline$>51 \mathrm{y} 1 \mathrm{l}$ & 15 & 5,8 \\
\hline Eğitim düzeyleri & & \\
\hline İlkokul & 139 & 53,9 \\
\hline Ortaokul & 61 & 23,6 \\
\hline Lise & 30 & 11,6 \\
\hline Ön lisans & 4 & 1,6 \\
\hline Lisans (Gıda Müh, Kimya Müh., Vet Hek.) & 24 & 9,3 \\
\hline Mesleki deneyim & & \\
\hline 1 yıla kadar & 26 & 10,1 \\
\hline $1-5$ y1l & 91 & 35,3 \\
\hline $6-10$ y1l & 81 & 31,4 \\
\hline $11-20$ y1l & 60 & 23,3 \\
\hline
\end{tabular}

Çizelge 2 İşletmelerin kapasite profili

\begin{tabular}{|c|c|c|c|c|}
\hline İşletme No & Resmi (R) / Özel (Ö) & İlçe & Personel Sayıs1 & Reel Üretim Kapasitesi (adet tabldot/gün) \\
\hline 1 & $\mathrm{R}$ & Alaçam & 7 & 2500 \\
\hline 2 & Ö & Bafra & 5 & 80 \\
\hline 3 & $\ddot{O}$ & & 8 & 550 \\
\hline 4 & Ö & & 5 & 250 \\
\hline 5 & Ö & & 4 & 200 \\
\hline 6 & $\mathrm{R}$ & Atakum & 26 & 3250 \\
\hline 7 & Ö & & 7 & 600 \\
\hline 8 & $\mathrm{R}$ & & 33 & 8500 \\
\hline 9 & Ö & & 4 & 750 \\
\hline 10 & $\ddot{O}$ & & 5 & 100 \\
\hline 11 & Ö & Çarşamba & 11 & 4000 \\
\hline 12 & $\ddot{O}$ & & 9 & 3600 \\
\hline 13 & Ö & & 7 & 3800 \\
\hline 14 & $\ddot{O}$ & & 20 & 4000 \\
\hline 15 & Ö & & 11 & 1000 \\
\hline 16 & Ö & $\dot{I} 1_{\mathrm{r}} \mathrm{d}$ & 13 & 700 \\
\hline 17 & Ö & Ilkadım & 4 & 80 \\
\hline 18 & Ö & & 6 & 1250 \\
\hline 19 & Ö & & 50 & 2500 \\
\hline 20 & Ö & & 7 & 200 \\
\hline 21 & Ö & Ladik & 13 & 1000 \\
\hline 22 & Ö & & 3 & 100 \\
\hline 23 & Ö & & 4 & 6500 \\
\hline 24 & Ö & & 9 & 125 \\
\hline 25 & Ö & Tekkeköy & 35 & 1500 \\
\hline 26 & Ö & & 30 & 4000 \\
\hline 27 & Ö & & 10 & 2250 \\
\hline 28 & $\ddot{O}$ & & 10 & 2300 \\
\hline 29 & Ö & Terme & 8 & 2200 \\
\hline 30 & Ö & Terme & 20 & 200 \\
\hline 31 & Ö & & 3 & 300 \\
\hline 32 & Ö & Vezirköprü & 6 & 5000 \\
\hline
\end{tabular}


Tabldot Yemek Üreten İşletmelere Ait Demografik Bulgular

$\mathrm{Bu}$ grupta, yemekhane üretiminde görevli personelin cinsiyeti, yaşı, eğitim düzeyi, mesleki tecrübe süresi (yıl), reel üretim kapasiteleri, makine gücü ve personel sayısına (üretim bölümü) ait bilgiler yer almaktadır. Çizelge 1'de mutfak bölümünde görevli kişilere ait demografik bilgiler mevcut olup erkek ve kadın çalışanların sayısının birbirine yakın olduğu, çalışanların \%38,8'inin 31-40 yaş aralığında olduğu, eğitim düzeyinin en fazla \%53,9'luk oranla ilkokul, sektördeki mesleki deneyimin en fazla $\% 35,3$ oranla $1-5$ yıl arasında olduğu belirlenmiştir. Mutfak personelinin görev dağılımlarına bakıldığında, servis elemanı ve aşçı yardımcısı, hazırlık elemanı olarak çalışan personel sayılarının birbirine yakın olduğu, istihdamı zorunlu personel olarak 32 işletmenin 18'inde ilgili meslek gruplarının mevcut olmadığı görülmüştür. Ayrıca, mutfak yönetimi ve işleyişinden sorumlu aşçıbaşı, anket yapılan işletmelerin \% 75 'inde yer almamıştır.

Akçadağ ve Yıldırım (2004) tarafindan Kocaeli ilinde faaliyet gösteren toplu yemek üreten işletmelerde çalışan yöneticilere yönelik geçekleştirilen saha araştırmasında, çalışanlarının \%25'inin gıda mühendisi olduğunu, \%11,4'ünün aşçıaşı, \%58,5'inin ise tekniker olarak görev yaptığını belirlemiştir. Boyacıŏglu (2003), İstanbul'da hazır yemek sektörüne hizmet veren 220 işletmede gıda güvenilirliği konusunda yapmış olduğu çalışmada, personelin \%56'sının ilkokul mezunu olduğunu, \%64'ünün çalışma sürelerinin $1-2,5$ yıl arasında değiştiğini bildirmiştir. Çalışmamıza benzer şekilde bu araştırmalarda da istihdam edilmesi gereken mühendis sayılarının yetersiz olduğunu ortaya konmuştur.

Çizelge 3 Üretim yeri koşulları ile ilgili koşullar

\begin{tabular}{|c|c|c|}
\hline Üretim yeri kaç bölümden oluşmaktadır? & $\mathrm{n}$ & $\%$ \\
\hline 1 & 28 & 10,9 \\
\hline 2 & 44 & 17,1 \\
\hline 3 & 11 & 4,3 \\
\hline 4 & 82 & 31,8 \\
\hline$\geq 5$ & 93 & 36,1 \\
\hline \multicolumn{3}{|l|}{ Duvar yüzeyleri hangi malzemeden oluşmaktadır? } \\
\hline ( n & 201 & 77,9 \\
\hline Yağlı boya & 27 & 10,5 \\
\hline Beton & 24 & 9,3 \\
\hline PVC & 6 & 2,3 \\
\hline \multicolumn{3}{|l|}{ İşletme yüzeylerinde yoğunlaşmayı önlemek amacı ile ne kullanılıyor? } \\
\hline 皮 & 185 & 71,7 \\
\hline Klima & 8 & 8,0 \\
\hline Yoğunlaşma olmuyor & 5 & 1,9 \\
\hline Pozitif basıç̧lı havalandırma & 4 & 16,3 \\
\hline \multicolumn{3}{|l|}{ Ön hazırlama bölümü var mı? } \\
\hline 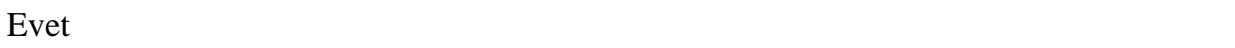 & 229 & 88,7 \\
\hline Hayır & 27 & 11,2 \\
\hline Personel soyunma/giyinme odası yaklaşık kaç metre karedir? & & \\
\hline$e^{2}$ & 36 & 14,0 \\
\hline 10 & 81 & 31,4 \\
\hline 20 & 107 & 41,5 \\
\hline$\geq 30$ & 28 & 10,9 \\
\hline Cevapsiz & 6 & 2,3 \\
\hline \multicolumn{3}{|l|}{ Tuvalet bölümünde yaşanan problemler hangisidir? } \\
\hline Sicak su temini & 83 & 32,2 \\
\hline Sifon kullanılamiyor & 58 & 22,5 \\
\hline Su kesintisi & 50 & 19,4 \\
\hline Temiz su temini & 6 & 2,3 \\
\hline Cevapsiz & 49 & 19,0 \\
\hline \multicolumn{3}{|l|}{ Mazgalların temizlik ve haşere kontrolü açısından durumu nasıldır? } \\
\hline Mazgallar sık aralıklı, haşere giremez, temizliğinde problem olmuyor. & 116 & 45,0 \\
\hline Mazgalların sökülüp takılması çok zor. & 55 & 21,3 \\
\hline Mazgallar geniş aralıklı, haşere riski bazen oluyor. & 34 & 13,2 \\
\hline Mazgalların bir kısmı kırık/yarık/çatlak, haşere girişi olabiliyor. & 20 & 11,6 \\
\hline Mazgal yok & 8 & 3,1 \\
\hline Cevapsiz & 15 & 5,8 \\
\hline \multicolumn{3}{|l|}{ Personel sayısına göre lavabo ve tuvalet dağılımı } \\
\hline 1-5 aras1 personel, 2 lavabo, 1 tuvalet & 49 & 19,1 \\
\hline $1-10$ arasi personel, 2 lavabo, 2 tuvalet & 80 & 31,1 \\
\hline $1-10$ arasi personel, 2 lavabo, 3 tuvalet & 43 & 16,6 \\
\hline $1-15$ arasi personel, 3 lavabo, 5 tuvalet & 85 & 32,9 \\
\hline Cevapsiz & 1 & 0,4 \\
\hline
\end{tabular}


Çizelge 4 Yemekhanede kullanılan ekipmanlarla ilgili koşullar

\begin{tabular}{|c|c|c|}
\hline Yemekhanede kullanılan alet-ekipmanlarda zamanla değişme (paslanma, aşınma, kararma vb.) oluyor mu? & $\mathrm{n}$ & $\%$ \\
\hline Evet & 217 & 84,1 \\
\hline Hayır & 34 & 13,2 \\
\hline Cevapsiz & 7 & 2,7 \\
\hline \multicolumn{3}{|l|}{ Yemeklerin taşınmasında hangi malzeme kullanıyorsunuz? } \\
\hline Paslanmaz çelik & 118 & 45,7 \\
\hline Termobox kaplar & 121 & 46,9 \\
\hline Çelik sefertası & 17 & 6,6 \\
\hline Cevapsiz & 2 & 0,77 \\
\hline Hijyen eğitimi alınan kurum adı & & \\
\hline Gıda, Tarım ve Hayvancılık İl Mdr. ve Halk Eğitim İl/İlçe Mdr. & 56 & 21,7 \\
\hline Milli Eğitim il/İlçe Mdr. ve Halk Eğitim İl/İçe Mdr. & 55 & 21,3 \\
\hline Yalnız Milli Eğitim il/İlçe Mdr. & 50 & 19,4 \\
\hline Milli Eğitim il/i̇lçe Mdr. ve Halk Sağlı̆̆ İl Mdr./Sağlık Ocağ1 & 30 & 11,6 \\
\hline Milli Eğitim il/İlçe Mdr. ve Gıda, Tarım ve Hayvancılık İl Mdr. & 14 & 5,4 \\
\hline Gıda, Tarım ve Hayvancılık İl Mdr. ve Halk Sağlığ İl Mdr./Sağlık Ocağı & 7 & 2,7 \\
\hline Cevapsiz & 31 & 12,0 \\
\hline
\end{tabular}

Çizelge 5 Personelin hijyen uygulamaları ile ilgili bilgi düzeyi

\begin{tabular}{|c|c|c|}
\hline Üretim yeri girişinde el dezenfektan dispenserleri bulunuyor mu? & $\bar{n}$ & $\%$ \\
\hline Evet & 220 & 85,3 \\
\hline Hayır & 32 & 12,4 \\
\hline Cevapsiz & 6 & 2,3 \\
\hline \multicolumn{3}{|l|}{ Dezenfeksiyon nedir? } \\
\hline Mikropları öldürmektir & 158 & 61,2 \\
\hline Deterjanla yıkamaktır & 34 & 13,2 \\
\hline Temizliktir & 28 & 10,9 \\
\hline Temizlikten sonra yapılan yıkamadır & 27 & 10,5 \\
\hline Fırçayla iyice ovalamaktır & 7 & 2,7 \\
\hline Cevapsız & 4 & 1,6 \\
\hline \multicolumn{3}{|l|}{ Dezenfeksiyonu ne ile yapıyorsunuz? } \\
\hline Dezenfektan ile & 146 & 56,6 \\
\hline Çamaşır suyu ile & 59 & 22,9 \\
\hline Sivı deterjan ile & 18 & 7,0 \\
\hline Kaynar su ile & 16 & 6,2 \\
\hline Köpüklü sabun ile & 12 & 4,7 \\
\hline Cevapsiz & 7 & 2,7 \\
\hline \multicolumn{3}{|l|}{ Büyük ekipmanların temizliği nasıl yapılıyor? } \\
\hline Tazyikli su ile & 101 & 39,1 \\
\hline Büyük tekne havuzlarında & 77 & 29,8 \\
\hline Fırça ile & 32 & 12,4 \\
\hline Yerde & 21 & 8,1 \\
\hline Makinede & 14 & 5,4 \\
\hline Cevapsiz & 13 & 5,0 \\
\hline \multicolumn{3}{|l|}{ Hangi sıklıkla atıkların ve diğer bulaşma kaynaklarının uzaklaştırılması sağlanıyor? } \\
\hline Her yemek hazırlığından önce ve sonra & 177 & 68,61 \\
\hline Çöp kovası dolduktan sonra uzaklaştırılıyor & 73 & 28,28 \\
\hline Vardiya değişiminde uzaklaştırılıyor & 6 & 2,33 \\
\hline Cevapsiz & 2 & 0,78 \\
\hline
\end{tabular}

Ankete katılan işletmelerin ilçelere göre kapasite değerleri, makine gücü ve üretimde görevli personel sayıları Çizelge 2'de verilmiştir. Buna göre, işletmelerin $\% 31,2$ 'sinin $<500, \% 21,8$ 'inin $>3750$ adet tabldot/gün reel üretim kapasitesine sahip olduğu ortaya konmuştur. İlçelere göre kıyaslama yapıldığında; Atakum ilçesinde resmi kuruma ait bir işletmede (8500 adet tabldot/gün), Tekkeköy'de özel bir işletmede (6500 adet tabldot/gün) ve Vezirköprü'de özel bir işletmede (5000 adet tabldot/gün) en yüksek kapasiteli üretim sağlandığı belirlenmiştir. Akçadağ ve Yıldırım (2004) tarafindan gerçekleștirilen çalışmada Kocaeli'nde faaliyet gösteren 37 adet toplu tüketim işletmelerinin \%13,5'inin 5000 ve daha fazla porsiyon, \%10,8'inin 2000-2999 porsiyon, \%45,9'unun 1000-1999 porsiyon, \%16,2'sinin 500-999 porsiyon ve $\% 8,1$ 'inin 499 ve daha az porsiyon günlük yemek ürettiği belirlenmiş olup 3000-3999 porsiyon ve 4000-4999 porsiyon yemek üreten birer ve 5000 üzeri 5 adet işletme bulunduğu ortaya konmuştur. İşletmelerin sadece \%9,38'inin potansiyel üretim kapasitesinin 50008500 adet tabldot/gün olarak belirlenmesi düşündürücüdür. Eğitim-öğretim kurumları, hastaneler, 
özel iş yerleri, fabrikalar göz önünde bulundurulduğunda, ilçeler bazında işletme sayılarının ve genel olarak üretim kapasitesinin düşük olduğu söylenebilir. Bununla birlikte işletmelerin üretim kapasiteleri ile personel sayıları arasında orantısal artış gözlenmemiş olup işletmelerin \%75'inin 3-12 arasında üretimde görevli personel istihdam ettiği belirlenmiştir.

\section{Iyi Hijyen Uygulamalarina Ait Bulgular}

İyi hijyen uygulamalarına ait sorular, üretim yeri koşulları ve hijyen uygulamaları kapsamında gruplandırılmıştır. Buna göre; 8 soru üretim alanı, 2 soru hammadde kabul ve izlenebilirlik, 4 soru soğuk zincir ve soğuk muhafaza, 5 soru hijyen uygulamaları, 1 soru hijyen yönetmeliği ile ilgili bilgi alma, 2 soru sıcak muhafaza kapları ve alet-ekipmanların paslanma, aşınma durumları ile ilgili olarak katılımcıların verdikleri cevaplar ve anket sahasındaki tespitler göz önünde bulundurularak değerlendirilmiştir. Çizelge 3 'te üretim yeri koşulları ile ilgili sorulara verilen yanıtlar gösterilmiştir.

Gerçekleştirilen çalışmaya göre, anket uygulanan işletmelerinin mutfaklarının en fazla 5 bölümden oluştuğu ve \%41,5'inin personel giyinme/soyunma odasının $20 \mathrm{~m}^{2}$ alana sahip olduğu belirlenmiştir. İşletme duvar yüzeylerinin temizlik ve dezenfeksiyon açısından uygun yapıda olduğu, işletmelerin \%71,7'sinin havalandırma amacı ile davlumbaz kullandığı, ancak üretim alanındaki yoğunlaşmayı önleyebilecek kapasitede olmadığı görülmüştür. Tuvalet bölümünde en fazla yaşanılan problemin sicak su temini, sifon kullanımı ve su kesintisi olduğu belirtilmiştir. Temizlik ve haşere kontrolü açısından önemli bir faktör olan işletmedeki mazgalların fiziki durumuna bakıldığında, işletmelerin \%45'inde mazgalların sık aralıklı olması nedeni ile sorun yaşanmadığı ve uygun olduğu görülmüştür. Geri kalan işletmelerde mevcut durumun iyileştirilmesi için gerekli önleyici tedbirlerin alınması gerektiği belirlenmiştir. Personel sayısına bağlı olarak tuvalet ve lavabo sayısı açısından değerlendirildiğinde, işletmelerin \%32,9'unda 1-15 arasında personel için 3 lavabo ve 5 tuvalet, $\% 31,1$ 'inde $1-10$ arası personel için 2 lavabo ve 2 tuvalet bulunduğu tespit edilmiştir.

Mutfakta kullanılan ekipmanların gida ile temasına uygunluğu ve sıcak muhafazada nakliye açısından kullanılan malzemelere yönelik soruların cevapları Çizelge 4'te yer almaktadır. Buna göre, işletmelerin büyük bir kısmında $(\% 84,1)$ yemekhanede kullanılan aletekipmanların zamanla paslanma, aşınma, kararma gibi durumlara maruz kaldığı belirtilmiştir. İşletmelerde kullanılan alet-ekipmanların bakım-onarım ve yenilenmeye ihtiyaç duyduğu ve iyi hijyen uygulamaları açısından elverişli hale getirilmesi gerektiği ortaya konmuştur. Yemeklerin taşınmasında çoğunlukla termobox ve paslanmaz çelik kapların kullanıldığı görülmüş olup, sıcak yemek servisi için gıdanın belirli bir sıcaklık değerinin korunabilmesi ve gida ile temasa malzeme uygunluğu açısından herhangi bir problem görülmemiştir. Personelin hijyen eğitimleri aldığı kurumlara bakıldığında, en fazla Gıda, Tarım ve Hayvancılık, Milli Eğitim ve Halk Eğitim İl/İlçe Müdürlükleri aracılığı ile eğitim verildiği görülmüştür. Bazı katılımcıların soruyu boş bırakması, konu ile ilgili bilgi sahibi olmadığını ve hijyen eğitimlerini almadığını göstermiştir. 5 Temmuz 2013 tarih ve 28698 sayılı "Hijyen Eğitim Yönetmeliğii" ne göre, gıda sektöründe çalışan personele hijyen eğitimi zorunluluğu getirilmiştir. Anket uygulaması yapılan tüm işletmelerde personelin zorunlu hijyen eğitim sertifikasına sahip olduğu görülmüştür.

Genel hijyen uygulamalarında personel tutum ve davranış düzeyini ortaya koymak amacıyla sorulan sorulara ilişkin cevaplar Çizelge 5'de verilmiştir. Personelin bu grupta verdiği teorik cevaplar ile işletmedeki tutum ve davranışları karşılaştırılmıştır. Buna göre, işletmelerin büyük çoğunluğunda $(\% 85,3)$ el dezenfektan dispanserlerinin mevcut olmasına karşın, kullanım alışkanlığının ve el hijyeni uygulamalarının yetersiz olduğu, hatta bazı mutfak personel tuvaletlerinde dispanserlerin boş olduğu gözlenmiştir. Büyük ekipmanların temizliği ile ilgili cevaplara göre, üretim alanı içerisinde bulaşıkhane kısmına daha fazla yer verilmesi gerektiği görülmüştür. Dezenfeksiyon kavramı ve dezenfeksiyon işlemi ile ilgili bilgiye dayalı sorulara katılımcıların yarısından fazlası doğru yanıt vermiştir. Bu bölümde katılımcılara, "hangi sıklıkla atıkların ve diğer bulaşma kaynaklarının uzaklaştırılmasının sağlandığı" sorusuna karşılık katılımcıların \%68,6'sı "her yemek hazırlığından önce ve sonra çöplerin uzaklaştırıldığını" belirtmiştir.

Çizelge 6 Personelin hammadde kontrolü ve izlenebilirlik kavramı ile ilgili bilgi düzeyi

\begin{tabular}{|c|c|c|}
\hline Hammadde kontrolünde hangi kriterlere bakılıyor? & $\overline{\mathrm{n}}$ & $\%$ \\
\hline Sicaklık ve etiket bilgileri & 167 & 64,7 \\
\hline Yalnızca etiket bilgileri & 44 & 17,1 \\
\hline Usta tecrübeleriyle anliyor & 21 & 8,1 \\
\hline Fatura/İrsaliye bilgileri & 17 & 6,6 \\
\hline Sicaklık & 5 & 1,9 \\
\hline Cevapsiz & 4 & 1,6 \\
\hline "İzlenebilirlik" ifadesinden ne anlıyorsunuz? & & \\
\hline İstenmeyen sorunun geriye doğru kaynağının saptanması & 115 & 44,6 \\
\hline İşlerin takibi & 75 & 29,1 \\
\hline İş yerinde standartların sağlanması & 37 & 14,3 \\
\hline Yemekhane ve diğer bölümlerin izlenebilir olması & 21 & 8,1 \\
\hline Ustanın yaptığ 1 işlerin bilinmesi & 9 & 3,5 \\
\hline Cevapsiz & 1 & 0,4 \\
\hline
\end{tabular}


Çizelge 7 Soğuk muhafaza ile ilgili koşullar

Soğuk zincirde $\left(0-4^{\circ} \mathrm{C}\right)$ gelmesi gereken hammaddelerin kabulünde yaptığınız işlem nedir? Araç sıcaklığı ve ürün sıcaklığına ayrı ayrı bakarım. $4^{\circ} \mathrm{C}$ 'den fazla ise kabul etmem. Son kullanım tarihi zaten kontrollü gelir.

Son kullanım tarihi ve ürün sıcaklık değerine bakarım. Tarihi yakın veya geçmiş ise ve sıcaklığ $4^{\circ} \mathrm{C}^{\prime} \mathrm{den}$ fazla ise kabul etmem.

Son kullanım tarihine bakarım.

Sıcaklığını ölçerim, $4^{\circ} \mathrm{C}^{\prime}$ den fazla ise kabul etmem.

Elle fiziksel kontrol yaparım. Yumuşak değilse kabul ederim. Son kullanım tarihi zaten kontrollü gelir. Cevapsiz

Soğuk muhafazası gerektiren farklı gıda gruplarını saklarken nelere dikkat edersiniz?

Et, süt ve kahvaltı gruplarını ayrı ayrı saklarım.

Aynı buzdolabı içinde et, süt ve kahvaltı gruplarını ambalajlı şekilde saklarım.

Çiğ ve pişmiş gıdaları ayrı olarak buzdolabında saklarım.

Et, süt ve kahvaltı gruplarını menüye göre aynı buzdolabında saklarım.

Hepsi

Hiçbiri

Cevapsiz

0 ile $4^{\circ} \mathrm{C}$ arasinda

$0^{\circ} \mathrm{C}^{\prime}$ nin altında

$4^{\circ} \mathrm{C}$ ile $7^{\circ} \mathrm{C}$ arasinda

Maksimum $2^{\circ} \mathrm{C}$

0 ile $10^{\circ} \mathrm{C}$

Cevapsiz

$100 \mathrm{~kg}$ derin dondurucuda $\left(-18^{\circ} \mathrm{C} /-20^{\circ} \mathrm{C}\right)$ muhafaza edilen eti nasıl çözündürürsünüz?

Taze et ve et ürünleri hangi sıcaklıkta muhafaza edilmelidir?

1 gece önce $100 \mathrm{~kg}$ eti olduğu gibi buzdolabına alırım

1 gece önceden $100 \mathrm{~kg}$ eti daha küçük parçalar halinde bölerek buzdolabında bekletirim.

$100 \mathrm{~kg}$ eti çözünene kadar dışarıda bekletirim.

$100 \mathrm{~kg}$ eti çabuk çözünmesi için kaynayan suya koyarım.

Günlük et geliyor

$100 \mathrm{~kg}$ etin çabuk çözünmesi için şeker serper kaynar suya koyarım.

Cevapsiz

Çizelge 6'da "hammadde kontrolünde hangi kriterlere bakıldığı" ve "izlenebilirlik" ifadesinden ne anladıkları sorusuna katılımcıların verdikleri cevaplar sunulmuştur. Hammadde kontrolünde mutfak personelinin en fazla sicaklık ve etiket bilgilerine dikkat ettiği (\%64,7), izlenebilirlik kavramı ile ilgili katılımcıların verdiği cevapların işletmedeki mühendislerin ifadelerine benzerlik gösterdiği görülmüştür. $\mathrm{Bu}$ nedenle kavramsal açıklamaya yönelik personelin cevaplarının güvenirliği konusunda çelişki ortaya çıkmaktadır. Fabrikaya satın alınan gıda maddelerinin gıda güvenilirliği kontrolü açısından çoğu işletmede prosedürlerin oluşturulmadığ 1 tespit edilmiştir.

Anket uygulamasında soğuk zincir ve soğukta muhafaza ile ilgili mutfak personelinin en fazla nelere dikkat ettikleri, taze et ve et ürünlerini hangi sıcaklıkta muhafaza ettikleri, dondurulmuş eti nasıl çözündürdükleri ile ilgili sorular sorulmuştur (Çizelge 7). Soğuk zincirde gelen hammaddenin kabulünde katılımcıların bir kısmının araç sıcaklığı ve ürün sıcaklığına $(\% 38,4)$, bir kısmının son tüketim tarihleri ve ürün sıcaklığına $(\% 32,6)$, bazılarının da sadece son kullanım tarihine baktıkları $(\% 15,9)$ görülmüştür. Soğukta muhafaza edilmesi gereken gıda maddelerinin soğuk zincir kesintisine uğramaksızın sevkiyat1, hazırlanması ve işlenmesi gerekmektedir. Hammaddelerin ve gıda maddelerinin satın alınmasından sorumlu kişinin gıda mevzuatına uygunluğunu ve tazeliğini kontrol etmesi gerekmektedir. Üretici tarafindan belirlenen ve ürün etiketindeki muhafaza sıcaklığına ve nakliye aracının sicaklık değerlerine uyulup uyulmadığ 1 kontrol edilmelidir. Bu kapsamda, katılımciların kısmen uygun cevaplar verdikleri görülmüştür. $\mathrm{Bu}$ bölümde yer alan " $100 \mathrm{~kg}$ derin dondurucuda $\left(-18^{\circ} \mathrm{C} /-20^{\circ} \mathrm{C}\right)$ muhafaza edilen eti nasıl çözündürürsünüz?" sorusuna, katılımcıların \%62'si “100 kg eti olduğu gibi buzdolabına alırım” şeklinde olmuştur. Bilindiği üzere, büyük parçalar halinde dondurulmuş gıdaların, buzdolabı sıcaklığında çözündürme sürecinde iç kısımların daha geç çözüneceği için bozulma belirtileri gösterecektir. $\mathrm{Bu}$ durumda mikrobiyal kaynaklı hastalıklar ve gida zehirlenmeleri riski meydana gelecektir. Kimyasal ve biyolojik açıdan potansiyel tehlikeler oluşturabilecek bu işlem için katılımcıların verdiği cevaplar maalesef mutfak personelinin gıdaların muhafazası, dondurularak muhafaza edilen gıdaların çözündürülmesi işlemleri konularında oldukça yetersiz olduğunu ortaya koymuştur. Hijyen esasları ve iyi uygulama kılavuzunun 7.3. ve 9.2.3. bölümlerinde "Dondurulmuş Gıda Maddelerinin Kullanımı ve İşlenmesi” ile ilgili bilgiler yer almaktadır (Anonim, 2011b). Buna göre, işlemlerin yürütülmesi ve personelin bu konuda bilgilendirmesi gerekmektedir.

Mutfakların çoğunda $(\% 88,7)$ ön hazırlama bölümü olmasına karşılık et ve et ürünleri, fırın ürünleri, sebzemeyve hazırlama, pişirme bölümü, bulaşıkhane, personel soyunma/giyinme ve duş odası, tuvalet/lavabo, kuru erzak deposu ve soğuk hava depolarının bulunduğu bölümlerin 
yer alması gerektiği düşünüldüğünde, işletmelerde en fazla 4 bölümün $(\% 31,8)$ bulunması ve bunların arasında soyunma odasına düşen alanın en fazla $20 \mathrm{~m}^{2}$ olması tasarım ve yerleşim açısından mutfak alanının yeterli büyüklükte olmadığını göstermektedir. Yeteri kadar temiz su ve kullanılmış su uzaklaştırma tesisleri bulunmayan bölgelerde kolera, tifo gibi salgın hastalıklar ortaya çıkmaktadır. Su tedarikinin içilebilir su niteliğinde ve kesintisiz sağlanması gerekmektedir (Atasoy, 2008). El yıkama lavabolarında kesintisiz sıcak ve soğuk su sistemi bulunmalıdır. Gıda üretimi yapılan alanlarda lavabo sayısı işletmenin büyüklügüne göre belirlenmelidir. Üretim alanlarında her 5 işçi için en az 1 lavabo bulundurulması gerekmektedir (Coşar, 2012). Buna göre, anket uygulanan yemekhanelerde belirlenen lavabo ve tuvalet sayılarının uygun olduğu söylenebilir. Atıklar, gıda maddelerinin bulunduğu mekânlardan y1ğılmalara meydan vermemek için mümkün olduğunca hızlı bir şekilde uzaklaştırılmalıdır. Üzerleri örtülebilen kaplar içinde çöp poşeti vb. maddelerin içinde toplanmalıdır. Atık yönetimi konusunda, katılımcıların verdiği cevaplar ve işletme koşulları göz önünde bulundurulduğunda gerekli tedbirlerin alındığı görülmüştür.

Elde edilen veriler, son yillarda talebi giderek artan Catering sektörüne cevap verebilecek yeterli kapasitenin olmadığını ortaya koymuştur. Bununla birlikte, yemekhanelerin fiziki alan koşullarının iyileştirilmesine, mutfak alanında bölümlerin işlemlere göre oluşturulmasına, daha fazla hijyenik tasarım yaklaşımı profiline ihtiyaç duyulduğu görülmüştür. İşletmelerde istihdam edilen personel sayısının ve eğitim düzeylerinin uygulamalı olarak arttırılması için gerekli çalışmaların ilgili sivil toplum kuruluşları ile iş birliği halinde yürütülmesi gerektiği görülmektedir. Gıda hijyeni ve personel hijyeni konularında, öncelikle işletmenin sorumlu mühendisi tarafından bilgilendirilme ve güncellemelerin yapılması, satın almadan sorumlu kişilerin gıda güvenirliği konusunda eğitilmesi ve uygulanan tüm işlemlerin kontrol kayıtlarının düzenli şekilde oluşturulması gerektiği görülmüştür. Hijyen eğitimlerinin alınmasına karşın, farklı gıda sektörleri için Gıda, Tarım ve Hayvancılık Bakanlığı ve ilgili sivil toplum kuruluşları ile ortaklaşa hazırlanan "İyi Hijyen Uygulamaları Rehberi"nde belirtilen gerekliliklerle ilgili personelin ve teknik kadronun eğitim desteği alması gerekmektedir. Kullanılan alet-ekipmanların gida ile temasa uygunluğunun sağlanması gerektiği, hammadde kabulünde gıda gruplarına göre iyi hijyen uygulamaları gerekliliklerinin ve kontrol-kayıt işlemlerinin yetersiz olduğu, dondurulmuş gıdaların çözündürülmesi, personel hijyeni, alet-ekipman ve yüzeylerin temizlik ve dezenfeksiyon işlemleri ve atık yönetimi ile ilgili tespit edilen bilgi eksikliklerinin giderilmesi için, uygun bir eğitim programı ve tüm işlemlerle ilgili talimatların/prosedürlerin oluşturulması ve buna uygun işlemlerin yürütülmesi gerekmektedir. İşletmelerin tedarikçi kontrolü/geriye yönelik olarak sorun teşkil eden kaynağın nasıl, hangi yollarla izlenebileceği, nasıl tedbirler alınması gerektiği gibi konularda hammaddelerin kabulünden pişirme-servis sonuna kadar tüm zinciri kapsayan Ön Gereksinim/Operasyonel Ön Gereksinim programlarının oluşturulması ve tehlike ve risk analizlerinin yapılması gerekmektedir. Saha gözlemlerinde mutfak bölümlerinde yer alan soğuk hava depo hacimlerinin yetersiz olduğu görülmüş olup mutfak kapasitesine bağlı olarak uygun hacim ve sayıda soğuk dolapların temin edilmesi gerekmektedir. Sonuç olarak, anketlerden elde edilen veriler ümit verici olup, gıda güvenliğinin sağlanması için gerekli tüm tedbirlerin alınması, hijyenik tasarım yaklaşımına göre bina koşullarının oluşturulması, uygulanabilir hijyen ve sanitasyon programı ve kontrolünün sağlanması, tedarik aşamasından servis sonuna kadar yapılan tüm iş ve işlemlerin izlenebilirliğinin sağlanması, tehlike ve risk analizlerinin yapılması gerekmektedir.

\section{Kaynaklar}

Akçadağ S, Yıldırım A. 2004. Toplu Yemek Üreticisi İşletmelerde Çalışan Yöneticilere İlişkin Ampirik Bir Çalışma. Gıda Mühendisliği Dergisi, 18-27.

Anonim. 2010. Veteriner Hizmetleri, Bitki Sağlığı, Gıda ve Yem Kanunu. 13 Haziran 2010 tarih ve 27610 sayıl1 Resmi Gazete. Erişim adresi: http://www.resmigazete.gov.tr/eskiler /2010/06/20100613-12.htm

Anonim. 2011a. Gıda, Tarım ve Hayvancılık Bakanlığı, Türk Gıda Kodeksi Mikrobiyolojik Kriterler Yönetmeliği. 29.12.2011 Tarih ve 28157 Sayılı Resmi Gazete. Erişim adresi: http://www.resmigazete.gov.tr/eskiler/2011/ 12/20111229M3-6.htm

Anonim. 2011b. Gıda, Tarım ve Hayvancılık Bakanlığı, Gıda Hijyen Yönetmeliği. 17 Aralık 2011 tarihli ve 28145 sayılı Resmi Gazete. Erişim adresi: http://www.resmigazete.gov.tr/ eskiler/2011/12/20111217-5.htm

Anonim. 2013. Gida İşletmelerinin Kayıt ve Onay İşlemlerine Dair Yönetmelikte Değişiklik Yapılması Hakkında Yönetmelik. 10 Ocak 2013 tarih ve 28524 sayıl Resmi Gazete. Erişim adresi: http://www.resmigazete.gov.tr/eskiler /2013/01/20130110-1.htm.

Atasoy D. 2008. Su temini. Harran Üniversitesi Mühendislik Fakültesi, Çevre Mühendisliği Bölümü ders notları. Erişim adresi: http://eng.harran.edu.tr/moodle/moodledata/8/ Ders_notlari/sutemini.pdf.

Beyhan Y. 1993. Hızlı Hazır Yemek (Fast-food) Sisteminde Hijyen, Hızlı Hazır Yemek Yeme Sistemi (Fast-food), sayfa 47. Türkiye Diyetisyenler Derneği, No:6, Ankara.

Bilgin B, Erkan ÜC. 2008. Bir Hazır Yemek İşletmesinde HACCP Sisteminin Kurulması. Tekirdağ Ziraat Fakültesi Dergisi, 5 (3): 267-281.

Boyacıŏlu D. 1996. İstanbul'daki Hazır Yemek Sektörü Bugün Hangi Noktadadır? Gıda Teknolojisi, 1(6): 35-43.

Boyacıoğlu D. 2003. Hazır Yemek Sektörünün Durumu. Tabldot, 26: 38-40.

Coşar Ş. 2013. Toplu Çalışma Alanlarında Biyolojik Ajanlar Ve Çalışan Üzerine Etkileri Önleme Yöntemleri. İş Sağlığı ve Güvenliği Genel Müdürlüğü, İş Sağlığı ve Güvenliği Uzmanlık Tezi, Ankara, 85s.

Dündar C, Elmacioğlu F, Topbaş M, Pekşen Y. 2000. Samsun İl Merkezindeki Hastane Mutfaklarının Hijyen Durumunun Değerlendirilmesi. Türk Hijyen ve Deneysel Biyoloji Dergisi, 57(1): 1-6.

Kılıç O. 2002. Hazır Yemek Sektöründe Gıda Güvenlik Sistemleri Uygulamaları ve Mevcut Durum Analizi. İstanbul Teknik Üniversitesi, Fen Bilimleri Enstitüsü, Yüksek Lisans Tezi, İstanbul, 68s.

Sezgin AC, Özkaya FD. 2013. Toplu Beslenme Sistemlerine Genel Bakış. Akademik Gıda 12(1): 124-128.

Sucu N, Durmuş S, Şen MA, 2008. Yemek Sektörüne Genel Bakış. Gıda Mühendisliği Dergisi, 35-39. Erişîm adresi: http://www.gidamo.org.tr/resimler/ekler/08dd52f2fe32a1d_e k.pdf?tipi $=5 \&$ turu $=$ H\&sube $=0$ 